\title{
STATISTICAL TRENDS OF SCHOOL SIZE, LOCATION AND ENROLMENT: AN EVALUATION OF PUBLIC JUNIOR SECONDARY SCHOOLS FOR SUSTAINABLE DEVELOPMENT
}

\section{iD Samuel Okpon Ekaette $^{1+}$ \\ (iD) Eyiene Ameh ${ }^{2}$ \\ Valentine Joseph \\ Owan ${ }^{3}$}

\author{
${ }_{1,2, s}$ Department of Educational Management University of Calabar, Calabar, \\ Nigeria. \\ Email:sammylucky2009@yahoo.com \\ •Email:eviencydan2h@yahoo.com \\ •Email:owanvalentine@gmail.com
}

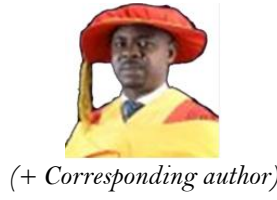

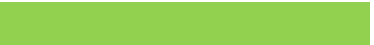

Article History

Received: 10 July 2020 Revised: 14 August 2020 Accepted: 7 September 2020 Published: 23 September 2020

\section{Keywords}

Enrolment

Location

Size

Trend

Secondary

Education

UBE.

\begin{abstract}
This is a trend study of School Size, Location and Enrolment Figures of Junior secondary schools in Akwa Ibom State of Nigeria covering 2008 - 2016 with implications on sustainable development. The study was tailored to follow the ex-post facto research design. This study was a census, hence the entire population of 227 public secondary schools were used. Secondary quantitative data were obtained using "School Size, Location and Enrolment Figures Checklist (SSLEFC)" were analysed using descriptive statistics, while line graphs and bar charts were used to illustrate the statistical trends. The hypotheses were tested using the independent t-test statistical approach. Findings showed that higher rates of enrolment were recorded in large and urban schools than in small schools and rural schools respectively. The mean differences in the enrolment trend among urban and provincial schools were factually huge. It was presumed that there is an upward pattern in enrolment in all the schools from 2008-2013 and a descending pattern from 2015-2016. Based on this conclusion, implications were discussed, while it was recommended, among others, that infrastructural provisions and adequate supply of qualified personnel be allocated to urban and rural schools evenly, to discourage rural-urban migration but promote active rural participation in Education, as well as foster sustainability in schools.
\end{abstract}

Contribution/Originality: This study contributes to existing literature by providing evidence on the influence of some institutional attributes on enrolment trends in upper basic education, from the perspective of a developing nation. The findings of this study have implications on the sustainability of school inputs particularly and secondary education generally.

\section{INTRODUCTION}

The significance of education as an amazing tool for the social, economic, moral and political development of any society cannot be overemphasized, especially in the $21^{\text {st }}$ century where the development of any nation is practically premised upon the degree of training acquired by the citizens. Junior secondary education is very strategic and unique to Nigeria. This is because it is a stage where the vocational thrust of basic education is consolidated and where core, vocational and non-prevocational academic subjects are taught, thereby providing ample opportunities for the teeming population of youths to acquire the basic skills needed to establish a solid foundation for self-development, moral values and aptitude for useful living and higher learning. It, therefore, implies that providing adequate access to junior secondary education is a feasible measure to building a progressive 
and a functional society where youths have positive self-concept; readiness to pursue life-long learning and contribute meaningfully to the development and advancement of society.

The Nigerian Government in recognition of this fact launched the Universal Basic Education (UBE) policy by the Former President Olusegun Obasanjo on $30^{\text {th }}$ September 1999 at Sokoto. This was meant to provide adequate access to all children of elementary and junior secondary school age in Nigeria through compulsory, free and universal nine-year education. It means that every child of the specified school age was supposed to have equal access to education irrespective of sex, class, location, ethnic group, socio-economic background and religion (Eddy \& Akpan, 2009). In Akwa Ibom State, the Ex-Governor Godswill Obot Akpabio had declared that free and obligatory education is essential since it provides equal opportunities for every Akwa Ibom child to have access to basic education (Ukpong, 2017).

This espouses the fact that the implementation of free and mandatory education in Akwa Ibom State is supposed to give equitable opportunities to every Akwa Ibom child from any location or region in the state, as it is stated in the Universal Basic Education Act of 2004. The universal implication of access in education is that all the people be entitled to training, paying little attention to their social class, ethnicity, ancestry or physical disabilities, to have an equal opportunity to educational services from which they can benefit and which directly borders on equity of instructive chances (Bolaji, 2014). Universal access to quality basic education, apart from being the right of every child, gives all school-age children an equal platform to attain their desired level of development and functionality in the society, irrespective of social-economic, regional, physical, gender and social class limitations. When more schools are established in some parts of a region than others, when some schools are more equipped than others in a given location, when more educational opportunities are allotted to some areas than others in a state, it offers ascend to the issue of inconsistent access to quality training among younger students and inconsistent ascent in school enrolment among schools in the area.

This uneven trend in school enrolment seems to be common in Nigeria, where more quality schools are concentrated in cities and rural areas have few and poorly equipped schools. This tends to give opportunities for more children in urban areas to attain quality education than their counterparts in rural who are likely to suffer from limited access and poor quality of teaching and learning. Despite the huge resources committed to ensuring adequate access to basic education in Akwa Ibom State through the full implementation of Universal Basic Education since 2008 (Ekaette, Ekpenyong, \& Owan, 2019) the issue of inequality in access to basic education seems apparent even as it is experiencing a rising trend in school enrolment. It is observed that schools with quality and well-equipped classrooms, libraries, laboratories and adequate teachers are sited in the urban and some strategic areas where there is a high concentration and interest of stakeholders (Arop, Ekpang, \& Owan, 2018). It is also noted that most of the schools in rural areas do not have standard and adequate classrooms, modern libraries and laboratories, adequate seats in classrooms, sufficient teachers especially in core subject areas like English Language, Mathematics, French, Introductory Technology and Home Economics (Ekaette et al., 2019; Owan, Duruamakudim, Ekpe, Owan, \& Agurokpon, 2019). Schools in rural areas of the state are occupied mostly by students from poor parents who could not afford to send their wards to quality schools in the urban areas (Owan et al., 2019).

This development contributes to the rural-urban migration of students in search of quality education in the cities, consequently leading to population explosion in some areas (Ekaette et al., 2019). This has after some time brought about expanded interest for education without a comparing increment in the flexibility of instruction in rural areas restricting access to quality instruction. This equally may have accounted for the disparity in the performance of students experienced among schools in different locations in Akwa Ibom State. Reducing inequality in access to quality basic education in Akwa Ibom State demands an intensive examination of the characteristics of schools which may have an enduring influence on enrollment. Based on this, the study seeks to provide answers to the question: how does school size and location influence the enrolment statistics in junior secondary schools in Akwa Ibom State, Nigeria from 2008 - 2016? 


\section{LITERATURE REVIEW}

\subsection{School Size and Enrolment Statistics}

School size is a critical factor in any school system, as it is a measure that has severally been used by policymakers across the globe in determining the functionality or otherwise of a school system in terms of effective teaching and learning, utilization available school facilities, school discipline and classroom management, among others (Altonji \& Mansfield, 2011). "School quality is an important predictor of educational attainment and labourmarket success and that school size is one potential measure of school quality over which policymakers have some control" (Altonji \& Mansfield, 2011). However, there has been an intensive argument on the implications of school sizes on trends in school enrolment. In the United States, it was established that specialized instructions are offered in larger schools than in smaller due to a high rate of administrative efficiency and a reduced cost per-head of students provided by the economies of scale such schools enjoy (Berry, 2006; Duncombe \& Yinger, 2007). A study asserts that schools with enrolments of 300 to 400 students were optimal for seven reasons, namely, governance, respect, simplicity, safety, parent involvement, accountability and belonging (Meier cited in Jones and Ezeife (2011)). The above expressions espouse the fact that researchers have different opinions about the implication of school sizes on enrolment issues in schools.

A curvilinear relationship has been recorded between school sizes and school enrolment indicating that high school achievement increased as enrolment levels rose to 600, stayed steady up to 900, and then decreased as enrolment size further rose (Lee \& Smith cited in Jones and Ezeife (2011)). A separate study discovered that as school size increases, the class size also increases and what number of students makes a large group and should constitute a small group is a matter of contention (Arop et al., 2018). The revised National Policy on Education specified a maximum of 40 students in class in secondary schools (Federal Republic of Nigeria, 2004). Some researchers believe that enrolment in schools, especially in secondary schools should be based on the school size and locations among others (Arop et al., 2018; Ekaette et al., 2019; Owan et al., 2019). No matter how laudable an educational programme may be, if the number of facilities needed to carry out the programmes is inadequate, the programme will not be as good as expected (Adeyemi \& Adu, 2010). The above expression implies that school enrolment should follow the available school facilities and the size of the school in terms of the number of classrooms.

The study of Jones and Ezeife (2011) revealed that grade-three writing and grade-six mathematics students in large and urban schools performed significantly higher than the standards set by the education authorities in the province. This implies that school size did not influence students' achievement, indicating that the school size with the proportionate provision of basic facilities may not significantly influence enrolment rate in the schools. The findings of Adeyemi (2009) disclosed that there were increment in the enrolment of students at the rate of $5.6 \%$, however, one notable problem is the shortage of teachers to cater for the diverse needs of learners. Thus, the supply of qualified instructors did not coordinate the interest for them in secondary schools in the state. It was recommended that the state government would require extra 3,585 instructors constantly in 2016.

It has likewise been indicated that there is a rise in enrolment growth rate in UBE schools, however, it was low in primary schools but high in junior secondary schools (Adeyemi \& Adu, 2010). The progression rates were high in both levels of education while the physical facilities were not adequate. It was concluded that the provision of physical facilities did not match the enrolment growth rate of pupils in primary and junior secondary schools in the State (Adeyemi \& Adu, 2010). The results from the study of Adeleke (2015) revealed that on the average, enrolments in junior secondary schools grew by $1.64 \%$. Similarly, Makori and Onderi (2014) concluded that some small and medium-sized secondary schools lacked libraries, laboratories and sports facilities. It implies that increasing school enrolment without recourse to the size of schools may lead to poor attainment of school goals and objectives. The outcomes from another investigation uncovered that enormous school locale size is adverse to 
accomplishment in fourth and seventh grades in Washington because it fortifies the negative connection between school neediness and understudy accomplishment (Abbott, Joireman, \& Stroh, 2002).

Multilevel findings of this study argued against the simplistic conclusion that reducing school or district size will automatically improve student achievement or result in more educational equity (Abbott et al., 2002). A study revealed that there are high enrolment trends in primary schools which led to the overworking of staff members, inadequate teaching and learning facilities, poor sanitation facilities and inadequate classroom (Mwirigi, 2015). The expanded enrolment affected by and large on the nature of learning in open elementary schools (Mwirigi, 2015). In another study (Vorthmann, 2010) revealed that students in larger schools outperformed their counterparts in smaller schools, higher. It implies that both large and middle schools do not experience similar performance in students' assessment, meaning that the sizes of the schools significantly influence enrolment trend in the area. It has likewise been uncovered, among others, that effective teaching, learning, assessment and records management are difficult to achieve in large class sizes due high rate of students' population pressure (Anashie, Ebuta, \& Adie, 2014). A possible reason is because of the differential effect that hampers the average achievement of students from low socioeconomic status as schools get larger (Bickel, Howley, Williams, \& Glascock, 2001). The researchers concluded that a traditional argument against smaller schools, however, is that they are simply too expensive to operate, regardless of proven benefits (Bickel et al., 2001). The researchers thus, subscribe to larger schools and increased enrolment on the grounds of the economics of scale in terms of costs effectiveness in running the school system. The results of Isuku (2016) indicated that enrolment and student-teacher-ratio factors were the strongest predictors of unit cost. All three size factors were inversely related to the unit cost (Isuku, 2016).

It has also been found that there is an expansion in class sizes of many schools with limited classrooms to cater for such changes in the enrolment of students (Epri, 2016). Furthermore, new teachers were not recruited to take care of the new additions or extra classes created, while many school drop-outs rarely return back to school, with only a few returns after several months of being out-of-school (Epri, 2016). Such increment in enrolments made learning to be very difficult for students due to the poor support offered by their over-worked teachers in such a poor learning environment (Epri, 2016). These results suggest that school size as far as the quantity of understudies, number of educators, school offices accessible affects student enrolment in schools.

\subsection{School Location and Enrollment Trend}

School location is a very crucial factor that must be considered in students' enrolment in schools. Where a school is situated says a lot about the achievement of students (Ma \& Wilkins, 2002). The area of schools as far as urban and rustic zones can apply an enduring impact on enrolment patterns in the territories. Clarifying the trademark contrasts among urban and rustic territories. Explaining the characteristic differences between urban and rural areas, Ezike in Owoeye and Yara (2010) kept up that urban situations are described by a high populace thickness containing profoundly changed and excellent spots while rural conditions are less populated with a low populace thickness with many confined and unvaried spots. Some scholars stressed that in Nigeria, rural life is uniform, homogenous and less complex than that of urban centres, with cultural diversity, which often is suspected to affect students' academic achievement (Ntibi \& Edoho, 2017). They clarified further that this is on the grounds that urban centres are better preferred for circulation of social comforts, for example, pipe-borne water, power, medicinal services offices while the rural territories are less preferred (Ntibi \& Edoho, 2017). According to them, urban schools in Nigeria are educationally more advantaged with many opportunities than their disadvantaged counterparts in rural areas with limited opportunities.

Furthermore, the results of Ntibi and Edoho (2017) did not find any significant mean difference in the performance of students in urban and rustic schools. Another investigation, be that as it may, revealed that the scholastic accomplishment of understudies in Senior School Certificate Examination (SSCE) is essentially unique among urban and rural secondary school students in favour of students in urban school (Owoeye \& Yara, 2010). 
However, the results did not explain reasons for the observed differences in the performance of students from rural and urban areas. Thus, it is interesting to know whether students in rural schools are disadvantaged in terms of school infrastructural provision which led to their low academic performance as compared to their counterparts in urban schools. Thus, further research is still necessary even though (Onah, 2011) speculated that urban students would always achieve more than the rural students because of the disparity in educational resources.

Other studies (e.g., (Agbaje \& Awodun, 2014; Ezeudu \& Obi, 2013; Yusuf \& Adigun, 2010) also did not find a statistically significant mean contrast in the academic accomplishment levels of urban and rural school students. This finding disagrees with the position of other studies (e.g., (Ahiaba \& Igweonwu, 2003; Ellah \& Ita, 2017; Owoeye \& Yara, 2010) which showed, on the contrary, that chemistry students in urban schools performed better with superior grades than their rural counterparts while failure rate was higher in the rural schools. Similarly, the study of Mhiliwa (2015) established that more extended distance by students to class made them arrive at schools late and with void stomachs. Location of school has prompted mass inability to the greater part of the students, due to the long walk among students, which could cause dropout (Mhiliwa, 2015). It was also discovered that many female students become pregnant and thus neglect to accomplish their instructive objectives due to rape on their way to school in rural areas (Mhiliwa, 2015). In line with this finding, Nwogu (2010) found that location was significant in learning aspects of mathematics with rural students exhibiting more learning difficulties than their urban counterparts.

\subsection{The Present Study}

The review of related writing x-rayed that many studies had been conducted with focus on areas such as school characteristics and students' achievement, school performance, students' performance, among others. However, it was noted to the best of the researchers' knowledge, that thorough direct experimental examinations had not been recorded on school size, area and enrolment figures in Akwa Ibom State, focusing on junior secondary schools. It was also noted that most of the empirical works reviewed did not use time series approach in their analysis. This has created a gap because data collected over a period is best treated as trends to determine whether or not there is stability or fluctuations, just as the degree of stability/fluctuations. The present study fills this gap by adopting a time series statistical approach based on data collected over a time period.

From the literature reviewed, it was shown in many studies that school size and location to affect understudies' choice of school; other studies disagreed with such a position by providing their own evidence, creating an argument in the literature. The inconclusive arguments in the literature warrants that more studies be conducted to clarify such arguments or contribute to the debate with newer evidence from varied contexts. It was based on this need that this study was also undertaken to show with evidence, the impact of school size and location on the enrolment activities of junior secondary schools using time series data covering the period 2008/2009 to $2015 / 2016$.

\section{METHODS}

The Ex-post Facto research design was adopted in this study. This design was considered relevant considering that this study intends to use records kept from activities which have already occurred in the past such that no manipulation is possible (Owan, Bassey, \& Ekpe, 2020). The study was carried out in the Akwa Ibom State of Nigeria. This state was created on the $23^{\text {rd }}$ of September, 1987, out of the former Cross River State. Akwa Ibom State comprised 31 Local Government Areas and has boundaries with Cross River State to the North, the Bight of Bonny to the South, Rivers State to the South-West, Imo and Abia State to the West, while the Cameroon Republic lies in the East. It lies between latitude $5^{\circ} 10^{\prime}$ and $4^{\circ} 20^{\prime}$ North of the Equator and $7^{\circ} 23^{\prime}$ East of Greenwich Meridian.

This study targets the entire 227 public secondary schools in Akwa Ibom State as the population. This population of schools is distributed across three education zones - Uyo, Eket and Ikot Ekpene with 84, 63 and 80 
schools respectively (Akwa Ibom State Secondary Education Board [AKSSEB], 2018). Census technique was adopted to enable the researchers explore the entire population without the need to sample. This approach is considered because the population is manageable and can be studied entirely. Population studies are considered superior to sampling since it involves a 100 percent representativeness, providing more confidence in making generalizations (Owan \& Bassey, 2019). It was possible to study the entire population because the study made used of enrolment data of the entire schools in the state.

Data for this study were collected through secondary sources using an instrument titled "School Size, Location and Enrolment Figures Checklist (SSLEFC)". The instrument was used to record the total enrolment of all the schools based on their characteristics from 2008 to 2016. The instrument received face validity from four experts (two in the Department of Educational Management and two in measurement and evaluation) in the University of Calabar. These experts checked for the adequacy and clarity of the items listed in the checklist to ensure that they were comprehensive. The corrections, modifications and suggestions offered were followed in preparing the final draft used for data collection.

A written request was sent to the Chairman, Akwa Ibom State Secondary Education Board to be able to access the data needed. Two research assistants were engaged to assist in collating the data provided using the "School Size, Location and Enrolment Figures Checklist (SSLEFC)". Data collected were coded into a spreadsheet programme and analyzed using SPSS and MS-Excel 2019. The output of the analysis including relevant dashboards were created to illustrate the trends, while independent t-test was used to test the hypotheses.

\section{RESULTS}

\subsection{Research Question One}

What is the enrolment trend of large and small junior secondary schools from $2008-2016$ ? The result of the analysis is presented in Table 1.

Table-1. Percentage enrolment statistics in large and small junior secondary schools from 2008-2016.

\begin{tabular}{|c|c|c|c|c|c|c|c|c|}
\hline $\begin{array}{c}\text { Years/ } \\
\text { School size }\end{array}$ & $\begin{array}{c}2008 / 09 \\
(\%)\end{array}$ & $\begin{array}{c}2009 / 10 \\
(\%)\end{array}$ & $\begin{array}{c}2010 / 11 \\
(\%)\end{array}$ & $\begin{array}{c}2011 / 12 \\
(\%)\end{array}$ & $\begin{array}{c}2012 / 13 \\
(\%)\end{array}$ & $\begin{array}{c}2013 / 14 \\
(\%)\end{array}$ & $\begin{array}{c}2014 / 15 \\
(\%)\end{array}$ & $\begin{array}{c}2015 / 16 \\
(\%)\end{array}$ \\
\hline Large & $\begin{array}{l}202 \\
(64) \\
\end{array}$ & $\begin{array}{l}258 \\
(66) \\
\end{array}$ & $\begin{array}{l}279 \\
(64) \\
\end{array}$ & $\begin{array}{l}298 \\
(63) \\
\end{array}$ & $\begin{array}{l}309 \\
(64) \\
\end{array}$ & $\begin{array}{l}326 \\
(64) \\
\end{array}$ & $\begin{array}{l}319 \\
(64) \\
\end{array}$ & $\begin{array}{l}293 \\
(64) \\
\end{array}$ \\
\hline Small & $\begin{array}{r}116 \\
(36) \\
\end{array}$ & $\begin{array}{r}134 \\
(34) \\
\end{array}$ & $\begin{array}{r}154 \\
(36) \\
\end{array}$ & $\begin{array}{r}173 \\
(37) \\
\end{array}$ & $\begin{array}{r}176 \\
(36) \\
\end{array}$ & $\begin{array}{l}180 \\
(36) \\
\end{array}$ & $\begin{array}{l}181 \\
(36) \\
\end{array}$ & $\begin{array}{r}163 \\
(36) \\
\end{array}$ \\
\hline Total & 318 & 392 & 433 & 471 & 485 & 506 & 499 & 456 \\
\hline
\end{tabular}

The result in Table 1 shows that the trend of enrolment for large and small junior secondary schools increased steadily from 2008/2009 with an average of 202 for large schools and 116 for small schools to 2013/2014 with an average of 325 for large schools and 180 for small schools. In 2014/2015, enrolment trend in both large and small schools started declining slowly with an average mean of 319 for large schools and 181 for small schools and kept declining to 293for large schools and 163 for small schools in 2015/2016. The analysis also shows that enrolment was significantly high in large schools than in small schools in all the years except for 2014-2016. This is further illustrated in Figure 1. 


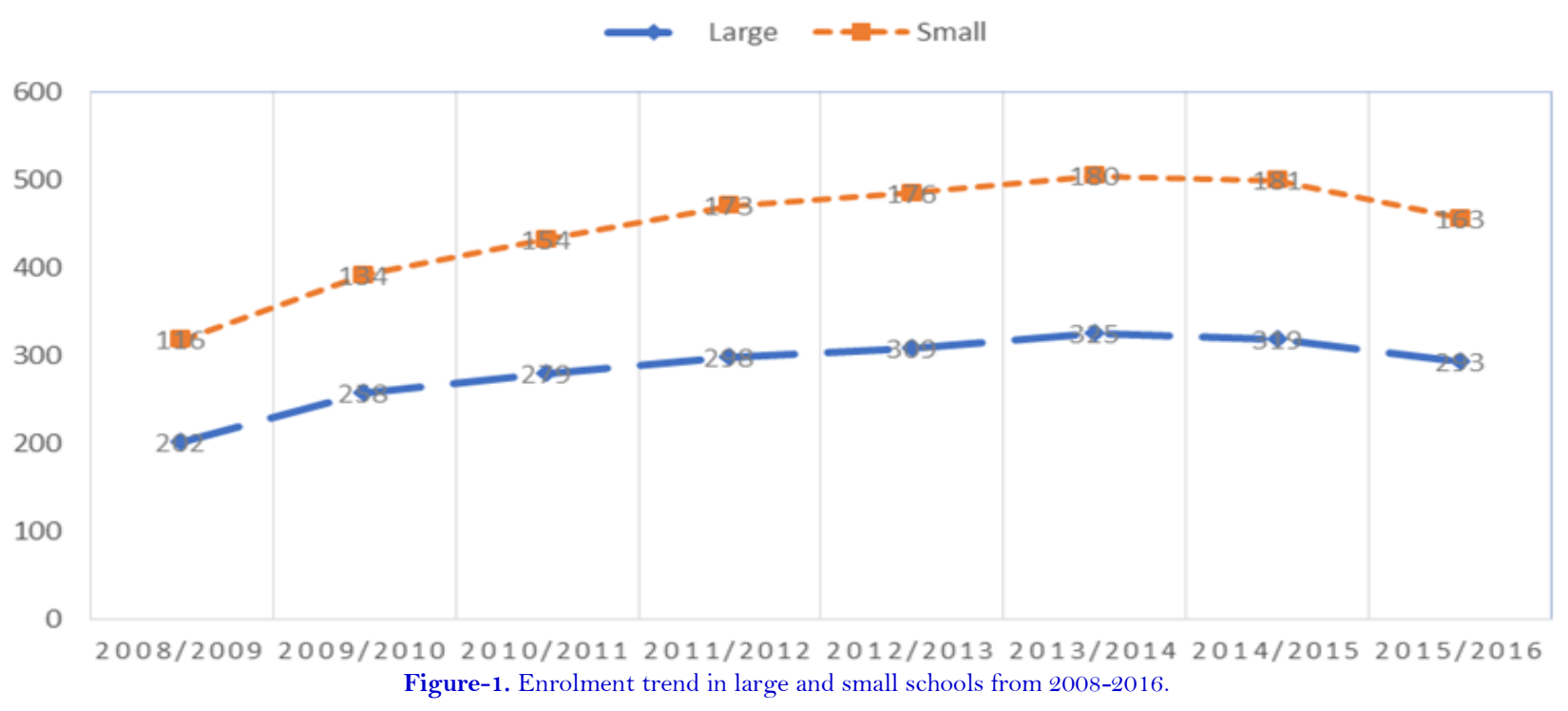

The result of the analysis in Figure 1 revealed that there was a steady increase in enrolment of large and small junior secondary schools from 2008/2009 up to 2013/2014, after which it started declining from 2014/2015 and continued in 2015/2016. This result also revealed that there was a large and significant increase in successive enrolment of large schools, than small schools in all the years in question.

\subsection{Research Question Two}

What is the enrolment trend of junior secondary schools in urban and rural areas from $2008-2016$ ? The result of the analysis is presented in Table 2.

Table-2. Percentage enrolment statistics in urban and rural junior secondary schools from 2008-2016.

\begin{tabular}{|c|c|c|c|c|c|c|c|c|}
\hline $\begin{array}{c}\text { Years/ } \\
\text { School location }\end{array}$ & $\begin{array}{c}2008 / 09 \\
(\%)\end{array}$ & $\begin{array}{c}2009 / 10 \\
(\%)\end{array}$ & $\begin{array}{c}2010 / 11 \\
(\%)\end{array}$ & $\begin{array}{c}2011 / 12 \\
(\%)\end{array}$ & $\begin{array}{c}2012 / 13 \\
(\%)\end{array}$ & $\begin{array}{c}2013 / 14 \\
(\%)\end{array}$ & $\begin{array}{c}2014 / 15 \\
(\%)\end{array}$ & $\begin{array}{c}2015 / 16 \\
(\%)\end{array}$ \\
\hline Urban & $\begin{array}{l}290 \\
(68)\end{array}$ & $\begin{array}{l}336 \\
(65)\end{array}$ & $\begin{array}{l}341 \\
(63)\end{array}$ & $\begin{array}{l}368 \\
(63)\end{array}$ & $\begin{array}{l}397 \\
(64)\end{array}$ & $\begin{array}{l}417 \\
(64)\end{array}$ & $\begin{array}{l}405 \\
(64) \\
\end{array}$ & $\begin{array}{l}383 \\
(65) \\
\end{array}$ \\
\hline Rural & $\begin{array}{r}139 \\
(32) \\
\end{array}$ & $\begin{array}{l}178 \\
(35)\end{array}$ & $\begin{array}{l}201 \\
(37)\end{array}$ & $\begin{array}{l}218 \\
(37)\end{array}$ & $\begin{array}{l}222 \\
(36)\end{array}$ & $\begin{array}{l}230 \\
(36)\end{array}$ & $\begin{array}{l}229 \\
(36)\end{array}$ & $\begin{array}{l}207 \\
(35)\end{array}$ \\
\hline Total & 429 & 514 & 542 & 586 & 619 & 647 & 634 & 590 \\
\hline
\end{tabular}

The result in Table 2 shows that the trend of enrolment of junior secondary schools in urban and rural areas increased consistently from 2008/2009 with an average of 290 for urban schools and 139 for rural schools to 2013/2014 with an average mean of 417 for urban schools and 230 for rural schools. In 2014/2015, enrolment trend in both urban and rural schools experienced a small decline with an average mean of 405 for urban schools and 229 for rural schools and continued declining slowly to 383 for urban schools and 207 for rural schools in 2015/2016. The analysis also indicates that junior secondary school enrolment was significantly high in urban schools than in rural schools in all the years covered except from 2014-2016. This is further illustrated in Figure 2. The result of the analysis in Figure 2 revealed that there was a steady increase in enrolment of urban and rural junior secondary schools in Akwa Ibom State from 2008/2009 up to 2013/2014 and declined from 2014/2015 and continued to fall in 2015/2016. This result also revealed that the increase in enrolment of urban schools was large and significant than that of rural schools in the state, in all the years in question. 


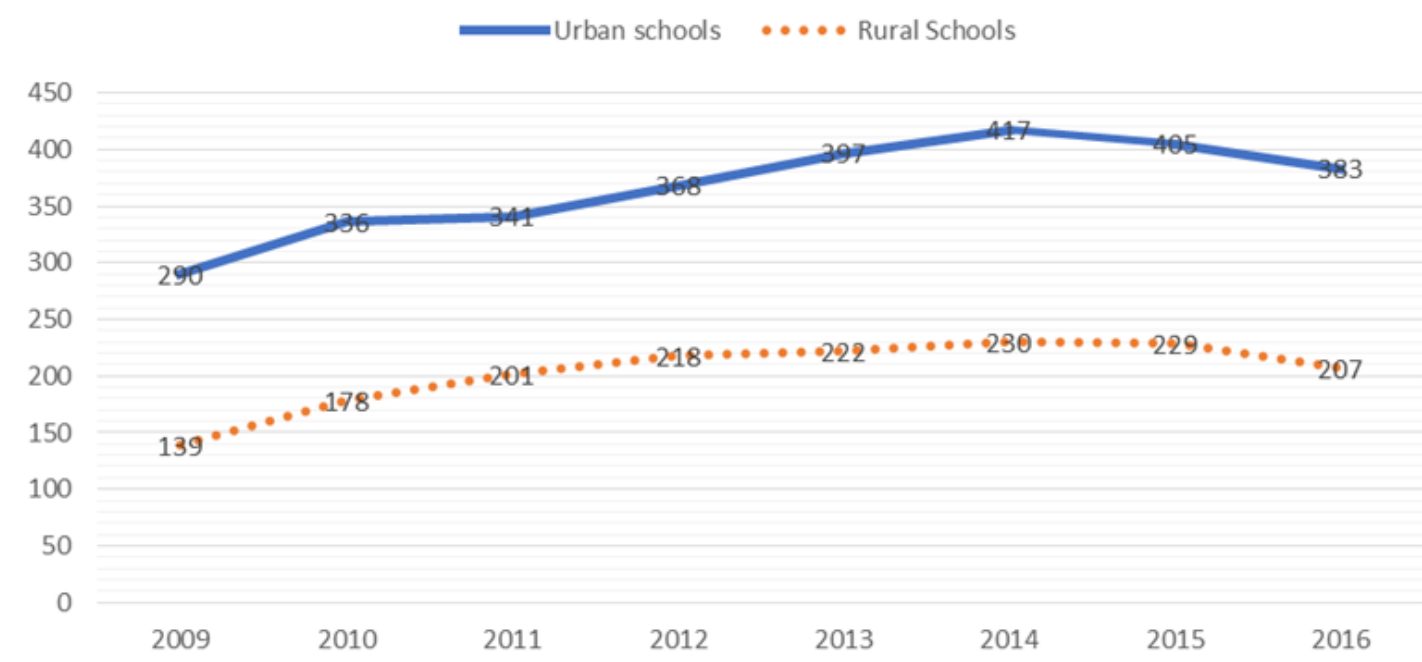

Figure-2. Enrolment trend based on school location (urban and rural) from 2008-2016.

\subsection{Hypothesis One}

There is no significant difference in enrolment trend of junior secondary schools from 2008 - 2016 based on school size. The result of this hypothesis is presented in Table 3. In Table 3, the independent t-test analysis indicates that $\mathrm{t}$ ratio ranging from 8.407 to 10.26 was obtained for the years under consideration. These t-ratios were all statistically significant at .05 probability level since $\mathrm{p}$ is less than .05 $(\mathrm{p}<.05)$. Based on this result, hypothesis one was rejected. Thus, suggesting that there is a statistically significant difference between large and small size schools in their enrolment figures. The result further shows that enrolment in large size schools was significantly higher than those in small size schools.

Table-3. Independent t-test comparison of school size and students' enrolment figures.

\begin{tabular}{|c|c|c|c|c|c|c|}
\hline Year & School size & $\mathbf{N}$ & $\overline{\mathrm{X}}$ & SD & $\mathbf{t}$ & Sig. \\
\hline \multirow[b]{2}{*}{ 2008/09 } & Large & 126 & 202.91 & 105.43 & & \\
\hline & Small & 99 & 116.12 & 50.945 & 7.527 & .000 \\
\hline \multirow[t]{2}{*}{$2009 / 10$} & Large & 126 & 258.83 & 102.07 & & \\
\hline & Small & 99 & 134.66 & 59.127 & 10.76 & .000 \\
\hline \multirow[t]{2}{*}{$2010 / 11$} & Large & 126 & 279.56 & 113.94 & & \\
\hline & Small & 99 & 154.86 & 66.185 & 9.679 & .000 \\
\hline \multirow[t]{2}{*}{$2011 / 12$} & Large & 126 & 298.71 & 129.83 & & \\
\hline & Small & 99 & 173.08 & 81.685 & 8.407 & .000 \\
\hline \multirow[t]{2}{*}{$2012 / 13$} & Large & 126 & 309.72 & 139.66 & & \\
\hline & Small & 99 & 176.11 & 70.618 & 8.683 & .000 \\
\hline \multirow[t]{2}{*}{$2013 / 14$} & Large & 126 & 325.04 & 145.58 & & \\
\hline & Small & 99 & 180.59 & 69.291 & 9.093 & .000 \\
\hline \multirow[t]{2}{*}{$2014 / 15$} & Large & 126 & 319.19 & 130.55 & & \\
\hline & Small & 99 & 181.37 & 72.569 & 9.419 & .000 \\
\hline \multirow[t]{2}{*}{$2015 / 16$} & Large & 126 & 293.97 & 127.34 & & \\
\hline & Small & 99 & 163.47 & 66.326 & 9.254 & .000 \\
\hline \multirow[t]{2}{*}{ Overall } & Large & 126 & 2287.93 & 902.142 & & \\
\hline & Small & 99 & 1280.26 & 492.340 & 10.00 & .000 \\
\hline
\end{tabular}

\subsection{Hypothesis Two}

There is no significant difference in enrolment trend of junior secondary schools from $2008-2016$ based on school location. The result of this analysis is presented in Table 4. 
Table-4. Independent t-test comparison of school location and students' enrolment figures.

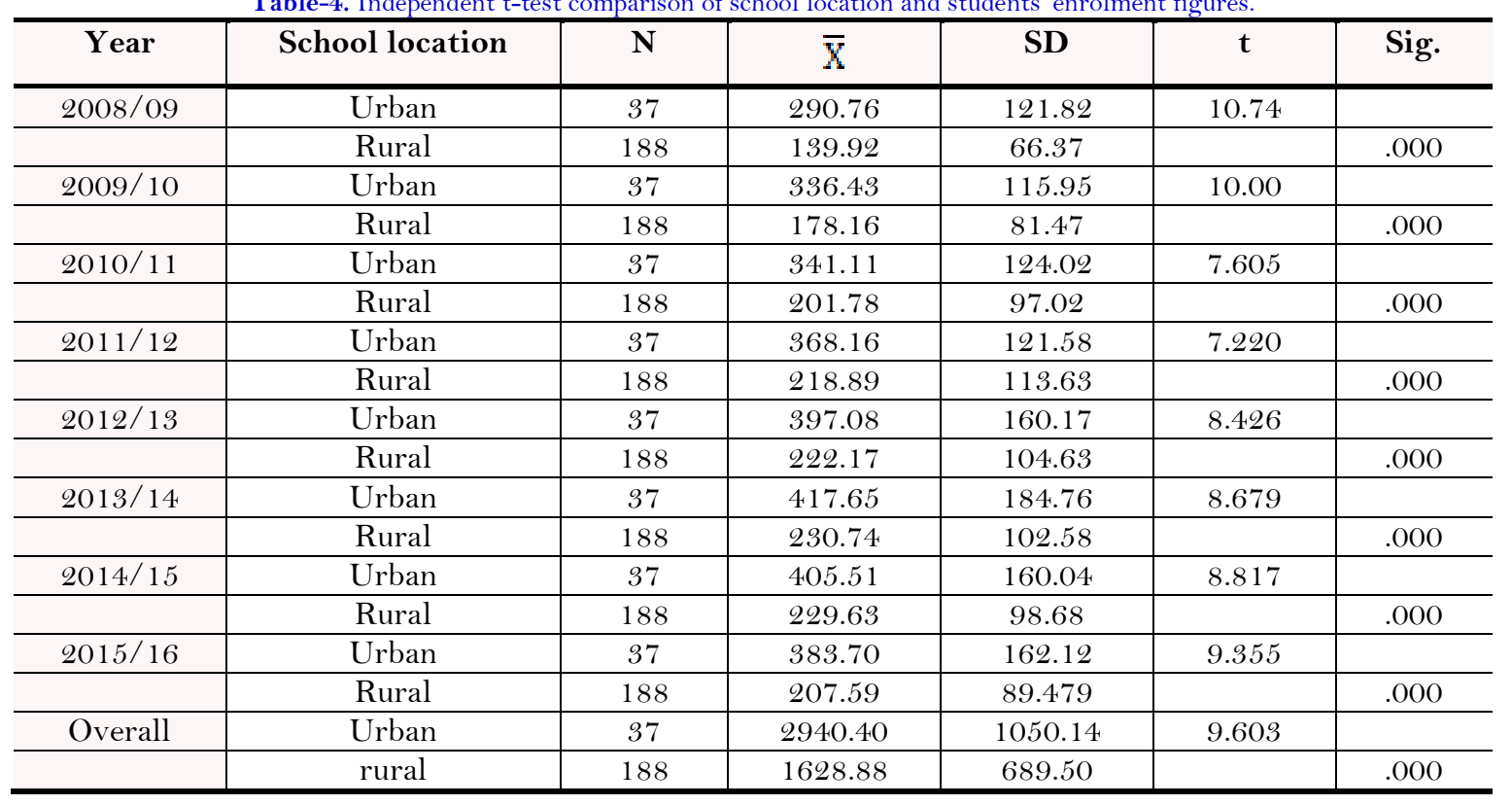

In Table 4, the independent t-test analysis indicates that $\mathrm{t}$ ratio ranging from 7.20 to 10.00 was obtained for the years under consideration. These t-ratios were all statistically significant at .05 probability level since p is less than $.05(\mathrm{p}<.05)$. Based on this result, hypothesis two was rejected. Suggesting that there is a statistically significant difference between urban and rural schools in their enrolment. The result further shows that enrolment in urban schools was significantly higher than those in rural schools.

\section{DISCUSSION OF FINDINGS}

The result of the analysis revealed that there was a steady increase in enrolment of large and small junior secondary schools from 2008/2009 up to 2013/2014, after which it started declining from 2014/2015 and continued in 2015/2016. This result also revealed that there was a large and significant increase in successive enrolment of large schools than in small schools in all the years in question. This difference in the enrolment trend of large and small schools in Akwa Ibom State within the years considered in the study is statistically significant. This result suggests that secondary schools in Akwa Ibom State that have a large number of classrooms, students, teachers and school buildings, had a significantly steady large increase in enrolment at junior secondary level within the years in question than those with a small number of students, personnel and school building.

The possible factor that could account for this steady increase in enrolment of large junior secondary schools and low enrolment in small school is population explosion in the cities as a result of rural-urban migration in Akwa Ibom State. Large secondary schools in Akwa Ibom State are mostly located in cities (where there is population exposition occasioned by rural-urban migration) and are well-equipped with quality infrastructure and personnel, thereby attracting students from villages. On the other hand, small schools are mostly found in villages and are disadvantaged in facilities and personnel (thereby discouraging parents from enrolling their wards in small schools). Because of this disparity in the quality and quantity of school resources and teaching and learning process between large and small schools in Akwa Ibom State, parents who desire quality education but resides in the village, enrol their children in large schools in the cities of Akwa Ibom State, thereby increasing enrolment of large schools.

Another factor that could contribute to the direction of this result is the high performance of large schools in Akwa Ibom State. Most of the large secondary schools in the state have adequate facilities and quality teachers and hence, sustains effective teaching and learning and students' high academic achievement in all subjects than small schools in the villages. Because of this high performance of large schools, parents from villages, who desire a quality education for their children, enrol their wards in large schools for better performance, thereby increasing 
enrolment in large schools in the State. This seems to agree with the findings of Bickel, et al (2001) who found that as school size increased, the achievement test score costs associated with the proportion of economically disadvantaged students enrolled in a school also increased. This implies that students who were from economically disadvantaged homes were able to secure high scores as they enrolled in large schools. This may be the reason parents in villages enrol their children and wards in large schools in the cities. This simply implies that factors influencing enrolment in large schools and small schools are different. Factors such as the performance of schools may contribute to this disparity in enrolment between large and small schools.

This is in line with Makori and Onderi (2014) who found that both medium and small schools in their study area lacked basic facilities and did not perform well. Contrary to this result, Epri (2016) found that there is an increase in class sizes of many schools with limited classrooms to cater for such changed in the enrolment of students. The researcher's argument here is that a large school does not lead to increased enrolment because of students' perceived difficulties in accessing quality teaching. This result may be that schools used for study did not have adequate facilities and teachers to contend the large school size. This implies that the adequacy of facilities and teachers in large and small schools may also influence enrolment.

The second major finding of this study showed an increase in enrolment of urban schools was large and significant than that of rural schools in the state, in all the years in question. This result suggests that although enrolment of the junior secondary in urban and rural areas of Akwa Ibom State rose consistently and dropped in the last two years of the period covered by this study, the increase in enrolment of urban schools was high and significant than that of rural schools. This observed disparity may be accounted for, by the fact that quality secondary schools in Akwa Ibom State mostly sited in an urban location where there is high population density. This finding supports the views of Ezike in Owoeye and Yara (2010) that urban environments are characterized by a high population density containing highly varied and beautiful places while rural environments are less populated with a low population density with many isolated and unvaried places. This may account for the high increased enrolment in urban schools as against the low increased in rural areas observed in the study. This result suggests that location factors imply the level of enrolment in schools.

The direction of this result is very clear in Akwa Ibom State in that there are more schools in urban areas than in rural areas. For instance, Uyo Local Government Area with a landmass of $362 \mathrm{~km} 2$, has 14 public secondary schools, while Oruk Anam Local Government Area with $524 \mathrm{~km} 2$, has 15 schools. Oruk Anam with such a large landmass as compared to Uyo is supposed to have more secondary schools. But because Oruk Anam is located in a rural area of the state, it has fewer schools than Uyo, despite its wider geographical coverage. This seems to give a clear understanding of the difference enrolment trend of schools in rural areas and schools in urban areas. Availability of educational facilities may also account for this result in the State. Secondary schools within urban areas in Akwa Ibom State are considerably equipped with modern facilities than those in rural areas. Politicians use schools in the urban areas of the State to demonstrate their political will, leading to availability of adequate infrastructure in the urban schools, thereby enhancing effective teaching and learning, and students' high performance, which catalyze increased enrolment. In line with this, Onah (2011) maintained that urban students would always achieve more than rural students because of the disparity in educational resources.

\section{CONCLUSION}

Based on the result of the data analysis, it is concluded that there is an upward trend in enrolment in all the schools from 2008 - 2013 and a downward trend from 2015 - 2016. It is further concluded that are statistically significant differences in the enrolment trend between large and small junior secondary schools, and between junior secondary schools in urban and rural areas. Finally, it is concluded that school size and school location significantly contribute to the variation in the enrolment figures of junior secondary schools in Akwa Ibom State within the period covered $(2008-2016)$. 


\section{RECOMMENDATIONS}

Based on the conclusion of the study, the following recommendations were made;

i. Government through the Ministry of education should increase spending and scholarship programmes for public schools as this will go a long way to encourage parents to enrol their wards in public schools.

ii. The Ministry of Education should increase awareness and publicity on co-educational schools as these will go a long way to reduce gender discrimination among parents in mixed schools.

iii. Infrastructural provisions and adequate supply of qualified personnel should be allocated to urban and rural schools evenly, to discourage rural-urban migration but promote active rural participation in Education.

Funding: This study received no specific financial support.

Competing Interests: The authors declare that they have no competing interests.

Acknowledgement: All authors contributed equally to the conception and design of the study.

\section{REFERENCES}

Abbott, M. L., Joireman, J., \& Stroh, H. R. (2002). The influence of district size, school size and socioeconomic status on student achievement in Washington: A replication study using hierarchical linear modelling. Technical Report. Washington: Washington School Research Center.

Adeleke, F. F. (2015). Relationship between school-based variables and the achievement level in secondary schools in Ekiti State. Journal of Management and Sustainability, 5(3), 107-113. Available at: https://doi.org/10.5539/jms.v5n3p107.

Adeyemi, T. (2009). The effective distribution of teachers into secondary schools in Ekiti State, Nigeria: A critical analysis. Current Research Journal of Social Sciences, 1(3), 74-83.

Adeyemi, T. O., \& Adu, E. T. (2010). Enrolment analysis and the availability of physical facilities for the universal basic education programme in Ekiti State, Nigeria. Middle-East Journal of Scientific Research, 5(1), 14-21. Available at: https://www.idosi.org/mejsr/mejsr5(1)/3.pdf.

Agbaje, R. O., \& Awodun, A. O. (2014). Impact of school location on academic achievement of science students in senior secondary school certificate examination. International Journal of Scientific and Research Publications, 4(9), 1- 4.

Ahiaba, J., \& Igweonwu, R. N. (2003). A comparative study of the performance of boys and girls in SSCE science subjects in Dekina L.G.A. of Kogi State. Unpublished B.Sc. Project. (University of Nigeria), Nsukka, Enugu State, Nigeria.

Akwa Ibom State Secondary Education Board [AKSSEB]. (2018). Public secondary school data in the state. Akwa Ibom State: Department of Planning and Statistics, Ministry of Education.

Altonji, J. G., \& Mansfield, R. (2011). The role of family, school, and community characteristics in inequality in education and labourmarket outcomes. In G. Duncan $\mathcal{O}^{\circ}$ R. Murnane (Eds.) Whither opportunity? Rising inequality, schools, and children's life chances. New York: Russell Sage Foundation.

Anashie, A. B., Ebuta, E. E., \& Adie, L. (2014). Influence of students' population pressure and class size on the academic performance of secondary school students in Cross River State. Multidisciplinary Journal of Research Development, 22(1), $1-17$.

Arop, F. O., Ekpang, M. A., \& Owan, V. J. (2018). Management of school-related variables and teachers' job effectiveness in secondary schools in Calabar South Local Government Area of Cross River State, Nigeria. International Journal of Social Sciences and Management Research, 4(8), 90-100.

Berry, C. R. (2006). School consolidation and inequality. Brookings Papers on Education Policy, 9(1), 49-75. Available at: https://doi.org/10.1353/pep.2007.0000.

Bickel, R., Howley, C., Williams, T., \& Glascock, C. (2001). High school size, achievement equity, and cost: Robust interaction effects and tentative results. Education Policy Analysis Archives, 9, 40. Available at: https://doi.org/10.14507/epaa.v9n40.2001.

Bolaji, S. D. (2014). Intent to action: Overcoming barriers to universal basic education policy implementation in Nigeria. Retrieved from: http://ro.ecu.edu.au/theses/1424. . 
Duncombe, W., \& Yinger, J. (2007). Does school district consolidation cut costs? Education Finance and Policy, 2(4), 341-375. Available at: https://doi.org/10.1162/edfp.2007.2.4.341.

Eddy, E., \& Akpan, M. (2009). The prospect of UBE programme in Akwa Ibom State, south-south Nigeria. International NGO Journal, 4(2), 046-049.

Ekaette, S. O., Ekpenyong, J. A., \& Owan, V. J. (2019). School characteristics and enrollment trend in upper basic schools in Akwa Ibom State, Nigeria from 2008-2016. Pedagogical Research, 4(3), emo039. Available at: https://doi.org/10.29333/pr/5855.

Ellah, K., \& Ita, P. (2017). Correlational relationship between school location and students' academic performance in English Language in Nigerian secondary schools. International Journal of Scientific and Research Publications, 7(9), 381-384.

Epri, M. L. (2016). A case study on the impact of large classes on student learning. Contemporary PNG Studies: DWU Research Journal, 24, 95-108.

Ezeudu, F., \& Obi, T. (2013). Effect of gender and location on students' achievement in chemistry in secondary schools in Nsukka local governmentarea of Enugu state, Nigeria. Research on Humanities and Social Sciences, 3(15), 50-55.

Federal Republic of Nigeria. (2004). National policy on education. Lagos: NERDC Publishers.

Isuku, E. J. (2016). Size factors as determinants of recurrent unit cost of public secondary education in edo State, South-South Nigeria. Journal of Educational and Social Research, 6(3), 125-125. Available at: https://doi.org/10.5901/jesr.2016.v6n3p125.

Jones, K. R., \& Ezeife, A. N. (2011). School size as a factor in the academic achievement of elementary school students. Scientific Research in Psychology, 2(8), 859-868. Available at: https://doi.org/10.4236/psych.2011.28131.

Ma, X., \& Wilkins, J. L. (2002). The development of science achievement in middle and high schoolr: Individual differences and school effects. Evaluation Review, 26(4), 395-417. Available at: https://doi.org/10.1177/0193841 x02026004003.

Makori, A., \& Onderi, H. (2014). Examining the teaching and learning resources related challenges facing small and mediumsized public secondary schools in Kenya: A comparative analysis. African Educational Research Journal, 2(2), 72-84.

Mhiliwa, J. A. (2015). The effects of school location on learner's academic performance: A case of community secondary schools in Makambako Town Council, Njombe. PhD Dissertation. Open University of Tanzania Tanzania.

Mwirigi, S. F. (2015). Impact of enrollment on the quality of learning in primary schools in Imenti central district, Kenya. Journal of Education and Practice, 6(27), 156-160.

Ntibi, J., \& Edoho, E. (2017). Influence of school location on students' attitude towards mathematics and basic science. British Journal of Education, 5(10), 76-85.

Nwogu, E. (2010). An inquiry into the major difficulties expressed/exhibited by junior secondary school students in solving problems involving angles. Unpublished B.Sc Project. University of Nigeria Nsukka, Enugu State, Nigeria.

Onah, E. (2011). Influence of sex and school location on students' achievement in agricultural science. African Journal of Science, Technology and Mathematics Education, 1(1), 96-102.

Owan, V. J., \& Bassey, B. A. (2019). Data management practices in educational research. In N. P. Ololube \& G. U. Nwiyi (Eds.), Encyclopedia of institutional leadership, policy, and management: A handbook of research in honour of Professor OzoMekuri Ndimele (Vol. 2, pp. 1251-1265). Port Harcourt, NG: Pearl Publishers International Ltd.

Owan, V. J., Duruamaku-dim, J. U., Ekpe, M. B., Owan, T. J., \& Agurokpon, D. C. (2019). School characteristics and secondary school teachers' work effectiveness in Abi Local Government Area of Cross River State. American Journal of Education and Information Technology, 3(1), 25-31. Available at: https://doi.org/10.11648/j.ajeit.20190301.15.

Owan, V. J., Bassey, B. A., \& Ekpe, M. B. (2020). Assessment of students' attitude towards test-taking in secondary schools in Afikpo Education Zone Ebonyi State, Nigeria. American Journal of Creative Education, 3(1), 1-9. Available at: https://doi.org/10.20448/815.31.1.9.

Owoeye, J. S., \& Yara, P. O. (2010). School location and academic achievement of secondary school in Ekiti State, Nigeria. Asian Social Science, 7(5), 170-175. Available at: https://doi.org/10.5539/ass.v7n5p170. 
Ukpong, N. N. (2017). Politics of educational policies implementation: Focus on Universal Basic Education in Akwa Ibom State. British Journal of Education, 5(13), 99-108.

Vorthmann, C. D. (2010). The relationship between school size and student achievement in Missouri. PhD Dissertation. (Baker University), Baldwin City, United States.

Yusuf, M. A., \& Adigun, J. T. (2010). The influence of school sex, location and type on students' academic performance. International Journal of Education and Science, 2(2), 81-85.

Views and opinions expressed in this article are the views and opinions of the author(s), World Journal of Vocational Education and Training shall not be responsible or answerable for any loss, damage or liability etc. caused in relation to/arising out of the use of the content. 